\title{
Three decades of using of gypsum under sodic water irrigation in coarse textured soils
}

\author{
P. K. Yadav ${ }^{1}$, M. K. Jat ${ }^{1}$, Abha Tikkoo ${ }^{1}$, S. S. Yadav ${ }^{1}$ and S. K. Sharma ${ }^{2}$ \\ ${ }^{1}$ Department of Soil Science, Chaudhary Charan Singh, Haryana Agricultural University, Regional Research \\ Station, Bawal-123501 (Haryana), INDIA \\ ${ }^{2}$ Department of Soil Science, Chaudhary Charan Singh, Haryana Agricultural University, Hisar-125004 (Haryana), \\ INDIA \\ *Corresponding author. E-mail. mukesh.rca@gmail.com
}

Received: December 04, 2015; Revised received: May 12, 2016; Accepted: August 03, 2016

\begin{abstract}
The aim of this study was to determine the long term use of sodic waters and gypsum on physico-chemical properties of coarse textured loamy sand soil. The study consisted of three natural occurring underground sodic waters and amendment gypsum in various cropping systems. The results demonstrated that sodic water irrigation significantly decreased infiltration rate $\left(1.46 \& 1.09 \mathrm{~cm} \mathrm{hr}^{-1}\right)$ and soil porosity $(35.66 \& 33.26 \%)$ and increased soil strength $(17.49 \&$ $\left.17.67 \mathrm{~kg} \mathrm{~cm}^{-1}\right), \mathrm{pH}(9.52 \&$ 9.66), exchangeable sodium percentage (48.00 \& 55.00), sodium adsorption ratio (45.14 \& 54.10 $\left.(\mathrm{mmol} / 1)^{1 / 2}\right)$ and calcium carbonate content $(2.15 \& 2.44 \%)$. The gypsum application significantly improved infiltration rate $\left(2.20 \mathrm{~cm} \mathrm{hr}^{-1}\right)$ and soil porosity $(38.7 \%)$ and reduced soil strength $\left(16.74 \mathrm{~kg} \mathrm{~cm}^{-1}\right)$, soil $\mathrm{pH}(9.35)$ exchangeable sodium percentage $(39.00)$, sodium adsorption ratio $\left(36.93(\mathrm{mmol} / 1)^{1 / 2}\right)$ over a period of thirty years. A significant $\mathrm{CaCO}_{3}$ build up in soil was also observed with gypsum application $(3.28 \% 4.56 \%)$ as compared to its content at the start of study. Thus, it is concluded that in coarse textured soils of North west India, sodic waters up to RSC $12.0 \mathrm{me} \mathrm{I-1}$ could safely be used crop production in combination with gypsum in loamy sand soil without any adverse effect on the physico-chemical characteristics of soil.
\end{abstract}

Keywords: Coarse textured soil, Gypsum, Soil properties, Sodic water

\section{INTRODUCTION}

The continuous increase in the earth's population requires increasing quantities of water for domestic, industrial and agricultural needs. The progressive requirement of more water for irrigating crops under limited water resources has led to use of poor quality water in agriculture (Ragab, 2005). The large and indiscriminate use of these waters causes secondary salinisation and sodification which affects plant growth and yield. Use of sodic waters influence the crop growth due to excessive accumulation of sodium in the rhizosphere which adversely affects the physicochemical properties causing nutritional disorders associated with high $\mathrm{pH} / \mathrm{ESP}$. High carbonate $\left(\mathrm{CO}^{-2}\right)$ and bicarbonate $\left(\mathrm{HCO}^{-1}\right)$ content in sodic water increases the sodium hazard of the water to a level greater than that indicated by the higher sodium adsorption ratio (SAR). High $\mathrm{CO}^{-2}$ and $\mathrm{HCO}^{-1}$ also tend to precipitate calcium carbonate and magnesium carbonate when the soil solution concentrates during soil drying because of which the concentrations of calcium and magnesium in soil solution are reduced relative to sodium and the SAR of the soil solution tends to increase. The high concentration of sodium also causes the subsequent loss of structure and reduces the infiltration rate (Prapager et al., 2012) and increases $\mathrm{pH}$, SAR and ESP in the soils and decreases crop yields (Sharma and Minhas, 2004).

The sodic waters can be gainfully exploited by using required amount of amendments, which basically depends upon the magnitude of their residual sodium carbonate (RSC) content. Soil amendments like gypsum $\left(\mathrm{CaSO}_{4} \cdot 2 \mathrm{H}_{2} \mathrm{O}\right)$ mitigate the adverse effect of sodic waters (Yaduvanshi and Swarup, 2005). It is most commonly used amendments for sodic soil reclamation and for reducing the harmful effects of high sodium irrigation water because of its solubility, low cost, availability and cause of handling (Deshmukh, 2014). The application of gypsum with sodic irrigation water has been established for raising crops but questions regarding its continuous use over period of time had to be answered as gypsum is a direct source of calcium and its addition in soil profile results in its precipitation as $\mathrm{CaCO}_{3}$ and soil may become calcareous in nature. The aim of this study was to assess the long term effect of sodic waters and gypsum on soil properties i.e. infiltration rate, porosity, soil strength, soil $\mathrm{pH}, \mathrm{EC}$, organic carbon content, SAR , ESP and calcium carbonate content of a loamy sand soil. 


\section{MATERIALS AND METHODS}

Study site : The study was conducted at Chaudhary Charan Singh, Haryana Agricultural University, Regional Research Station, Bawal, Haryana located in the low rainfall zone of southern Haryana (28.18 N, $76.58 \mathrm{E}$ and $266 \mathrm{~m}$ above mean sea level), India. In general, May - June are the hottest (21-46.8 o C temp.) while December-January are the coldest (015.8 o $\mathrm{C}$ temp.) months of the year. The site receives inadequate and erratic precipitation (350-550 $\mathrm{mm}$ ) during monsoon (July-September). The weather remains almost dry except occasional light showers during October to March. Thereafter, it is quite dry till monsoon arrives in June. The maximum evapo- transpiration rate of $14 \mathrm{~mm} /$ day is recorded in the month of June. Depth of under ground water is at $20 \mathrm{~m}$ and quality of irrigation water is brackish except in few pockets, good quality water is available.

Experimental details : The experiment was started in the micro plots of $3 \mathrm{~m} \times 3 \mathrm{~m}$ size in 1983 . The physicochemical characteristics of the experimental field, at the start of experiment are shown in Table 1. The field experiment was carried out in two factor randomized block design with three sodic waters and two amendments treatments i.e. no amendment $\left(\mathrm{G}_{0}\right)$ and gypsum ( 100 per cent neutralization of RSC of irrigation water above 2.8 me 1-1 $\left(\mathrm{G}_{100}\right)$. According to Water quality classification criteria (Eaton,1950), water having RSC > $2.5 \mathrm{me} / \mathrm{l}$ are classified as sodic water therefore, water with RSC $2.8 \mathrm{me}^{-1}$ was taken as control. Gypsum was applied at 100 per cent of the gypsum requirement (GR) defined as quantity of gypsum to be applied to neutralize RSC of sodic waters of 12 and 16 me $1^{-1}$ before pre-sowing irrigation of kharif and rabi crops. The treatments were replicated thrice in a two factor randomized design. The requisite amount of gypsum is calculated based on following formula

Amount of Gypsum $\left(\mathrm{kg} \mathrm{ha}^{-1}\right)=65 \times$ RSC of irrigation water (RSC of irrigation water 2.8)

$\mathrm{X}$ Number of irrigations to be applied The chemical composition of three sodic waters with varying residual sodium carbonate (RSC) of 2.8, 12.0 and 16.0me 1-1 used for study is given in Table 2 . The cropping systems of the zone namely fallow-wheat, pearl millet-wheat, cowpea-mustard, cluster beanwheat, fallow- mustard, chillies - wheat, American cotton- wheat, desi cotton-mustard, sorghum (fodder) mustard, sorghum (fodder) - wheat, pearl millet - mustard, dhaincha seed-wheat, sonamukhi (annual) and kalmegh- chandersur were taken. The recommended package of practices was followed to raise all crops in various cropping systems.

Soil sampling and analysis : The soil samples were collected from different treatment plots from $0-15,15$ $30,30-45,45-60,60-90$ and $90-120 \mathrm{~cm}$ after harvest of wheat crop in Rabi 2012-13. The surface soil samples 0-15 cm were analyzed for different soil physico- chemical properties using standard procedures except calcium carbonate content which was determined up to the depth of $120 \mathrm{~cm}$. Hydraulic conductivity of soil samples was determined under constant water head as outlined in USDA Handbook No. 60. In situ observations of infiltration rate were estimated with the help of closed-top infiltro-meter (Malik et al., 1984). The volume of water required replacing the quantity of water that entered into the soil was recorded as a function of time. Dispersion ratio was determined by using method given by Richards (1954).Soil strength was determined by penetrometer. Soil $\mathrm{pH}$ and EC (1:2; soil: water suspension) was determined in soil water extract by using $\mathrm{pH}$ meter and conductivity meter. Organic carbon was determined by Walkley and Black' s rapid titration method as described by Jackson(1973). Exchangeable sodium was extracted by $1 \mathrm{~N}$ ammonium acetate (pH 7.0) and sodium estimation was determined using flame photometer (systronics). The ESP of the soil was estimated by standard method as outlined in USDA, hand book-60 (Richard 1954). Calcium carbonate was estimated by Puri's volumetric method (1949). The replicated data were statistically analyzed to workout the significance of treatment after methods of Panse and Sukhatme ( 1978 ).

\section{RESULTS AND DISCUSSION}

Infiltration rate, porosity and dispersion ratio: The initial infiltration rate was $1.15 \mathrm{~cm} \mathrm{hr}-1$ at the start of experiment which increased significantly to $1.75 \mathrm{~cm} \mathrm{hr}$ -1 with use of 2.8 me 1-1 RSC irrigation water. The infiltration rate decreased significantly from 1.75 to $1.46 \mathrm{~cm} \mathrm{hr}-1$ and $1.09 \mathrm{~cm} \mathrm{hr}-1$ with the increase in RSC of irrigation water from 2.8 to 12.0 and 16.0 me 1-1, respectively (Table 3). About 16.8 and 37.7 per cent reduction in infiltration rate was observed in plots receiving 12.0 and 16.0 me 1-1 RSC waters, respectively as compared to control (RSC 2.8 me 1-1). The reduction in infiltration rate in soils irrigated with high RSC waters of 12.0 and 16.0 me1-1 could be due to the increase in ESP (Table 5). High sodium concentration causes soil dispersion and aggregate swelling (Warrence et al., 2003). The forces that bind clay particles together are disrupted when too many large sodium ions come between them. When this separation occurs, the clay particles expand, causing swelling and soil dispersion, ultimately clogging the micro pores in soil and decreases infiltration rate. Sharp reduction in infiltration rate of soil irrigated with sodic water was also observed by Emdad et al. (2006). Application of amendment gypsum improved the infiltration rate in sodic water irrigated soils. The infiltration rate increased significantly with gypsum application from 0.37 to $2.55 \mathrm{~cm} \mathrm{hr}-1$ and from 0.26 to $1.93 \mathrm{~cm} \mathrm{hr}-1$ in 12.0 and 16.0 me 1-1 RSC irrigation water irrigated soils, respectively. The increased infiltration rate of sodic water irrigated soil by application of gypsum 
P.K.Yadav et al. / J. Appl. \& Nat. Sci. 8 (3): 1456 - 1461 (2016)

Table 1. Physico-chemical characteristics of experimental soil at the start of experiment.

\begin{tabular}{cccccccc}
\hline $\begin{array}{c}\text { Soil } \\
\text { depth } \\
(\mathbf{c m})\end{array}$ & $\begin{array}{c}\text { Soil } \\
\text { Texture }\end{array}$ & $\begin{array}{c}\mathbf{p H} \\
\mathbf{( 1 : 2 )}\end{array}$ & $\begin{array}{c}\mathbf{E C}(\mathbf{1}: \mathbf{2}) \\
\mathbf{d S m}\end{array}$ & $\begin{array}{c}\mathbf{C a C O} \\
\mathbf{( \% )}\end{array}$ & $\begin{array}{l}\text { Organic } \\
\text { carbon } \\
(\boldsymbol{\%})\end{array}$ & $\begin{array}{c}\mathbf{C E C} \\
\mathbf{C m o l}\left(\mathbf{P}^{+}\right) \mathbf{k g}^{-\mathbf{1}}\end{array}$ & $\begin{array}{c}\text { Infiltration } \\
\text { rate } \\
\left(\mathbf{c m h r} \mathbf{-}^{\mathbf{1}}\right)\end{array}$ \\
\hline $0-15$ & LS & 9.25 & 0.50 & Traces & 0.13 & 3.9 & 1.15 \\
$15-30$ & LS & 9.30 & 0.70 & Traces & 0.06 & 4.0 & - \\
\hline
\end{tabular}

Values are mean of three replicates.

Table 2. Chemical composition of tube well waters tested (Values are mean of three replicates).

\begin{tabular}{|c|c|c|c|c|c|c|c|c|c|}
\hline $\begin{array}{l}\text { Sodic } \\
\text { water }\end{array}$ & $\begin{array}{c}\text { EC } \\
\left(\mathbf{d S m}^{-1}\right)\end{array}$ & RSC & $\mathrm{CO}_{3}{ }^{=}$ & $\begin{array}{l}\mathrm{HCO}_{3}^{-} \\
\left(\mathrm{me} \mathrm{l}^{-1}\right)\end{array}$ & $\mathrm{Ca}^{++}$ & $\mathrm{Mg}^{++}$ & & $\begin{array}{l}\text { SAR } \\
\left(\mathrm{mmol}^{-1}\right)^{1 / 2}\end{array}$ & $\begin{array}{l}\text { pH } \\
(1: 2)\end{array}$ \\
\hline 1. & 1.72 & 2.8 & Nil & 7.8 & 7.2 & 1.7 & 3.3 & 7.6 & 7.9 \\
\hline 2. & 1.93 & 12.0 & Nil & 14.0 & 5.6 & 0.4 & 1.6 & 19.3 & 8.1 \\
\hline 3. & 2.20 & 16.0 & 1.6 & 16.0 & 8.2 & 0.7 & 1.3 & 19.8 & 8.9 \\
\hline
\end{tabular}

Table 3. Effect of sodic waters and gypsum on infiltration rate, porosity and dispersion ratio.

\begin{tabular}{|c|c|c|c|c|c|c|c|c|c|}
\hline \multirow{2}{*}{$\begin{array}{l}\text { Sodic } \\
\text { water } \\
\left(\text { me l l }^{-1}\right)\end{array}$} & \multicolumn{2}{|c|}{$\begin{array}{l}\text { Infiltration rate } \\
\left(\mathrm{cm} \mathrm{hr}^{-1}\right)\end{array}$} & \multirow[b]{2}{*}{ Mean } & \multicolumn{3}{|c|}{$\begin{array}{c}\text { Porosity } \\
(\%)\end{array}$} & \multicolumn{3}{|c|}{ Dispersion ratio } \\
\hline & $\mathbf{G}_{\mathbf{0}}$ & $\mathbf{G}_{\mathbf{1 0 0}}$ & & $\mathbf{G}_{\mathbf{0}}$ & $\mathbf{G}_{\mathbf{1 0 0}}$ & Mean & $\mathbf{G}_{\mathbf{0}}$ & $\mathbf{G}_{10}$ & Mean \\
\hline 2.8 & 1.75 & 1.75 & 1.75 & 38.89 & 38.89 & 38.89 & 0.17 & - & 0.17 \\
\hline 12.0 & 0.37 & 2.55 & 1.46 & 31.87 & 39.45 & 35.66 & 0.20 & 0.19 & 0.20 \\
\hline 16.0 & 0.26 & 1.93 & 1.09 & 28.70 & 37.81 & 33.26 & 0.21 & 0.20 & 0.21 \\
\hline Mean & 0.79 & 2.24 & & 33.15 & 38.72 & & 0.20 & 0.19 & \\
\hline $\mathrm{CD}(05)$ & $\begin{array}{l}\text { Sodic } \\
\text { Gypsu } \\
\text { Sodic }\end{array}$ & $\begin{array}{l}.06 \\
\text { Gypsu }\end{array}$ & .10 & $\begin{array}{l}\text { Sodic } \\
\text { Gypsu } \\
\text { Sodic }\end{array}$ & $\begin{array}{l}.14 \\
\text { Gypsu }\end{array}$ & & $\begin{array}{l}\text { Sodic } \\
\text { Gypst } \\
\text { Sodic }\end{array}$ & $\begin{array}{l}\text { ter- } 0.01 \\
\text { NS } \\
\text { ter } x \text { Gy }\end{array}$ & -NS \\
\hline
\end{tabular}

Values are mean of three replicates.

Table 4. Effect of sodic waters and gypsum on soil strength, EC and organic carbon content.

\begin{tabular}{|c|c|c|c|c|c|c|c|c|c|}
\hline \multirow{2}{*}{$\begin{array}{l}\text { Sodic } \\
\text { water } \\
\left(\text { me l }^{-1}\right)\end{array}$} & \multicolumn{3}{|c|}{ Soil strength (kg cm-1) } & \multicolumn{3}{|c|}{$\operatorname{EC}\left(d S m^{-1}\right)$} & \multicolumn{3}{|c|}{ OC content $(\%)$} \\
\hline & $\mathbf{G}_{\mathbf{0}}$ & $\mathbf{G}_{\mathbf{1 0 0}}$ & Mean & $\mathbf{G}_{\mathbf{0}}$ & $\mathbf{G}_{\mathbf{1 0 0}}$ & Mean & $\mathbf{G}_{\mathbf{0}}$ & $\mathbf{G}_{\mathbf{1 0 0}}$ & Mean \\
\hline 2.8 & 15.53 & 15.53 & 15.53 & 0.36 & 0.36 & 0.36 & 0.29 & 0.29 & 0.29 \\
\hline 12.0 & 17.70 & 17.27 & 17.49 & 0.38 & 0.35 & 0.37 & 0.26 & 0.30 & 0.28 \\
\hline 16.0 & 17.90 & 17.43 & 17.67 & 0.42 & 0.33 & 0.38 & 0.22 & 0.23 & 0.23 \\
\hline Mean & 17.04 & 16.74 & & 0.39 & 0.35 & & 0.26 & 0.27 & \\
\hline \multirow[t]{3}{*}{$\mathrm{CD}(05)$} & \multicolumn{3}{|c|}{ Sodic water- 0.50} & \multicolumn{3}{|c|}{ Sodic water- 0.01} & \multicolumn{3}{|c|}{ Sodic water- 0.01} \\
\hline & \multicolumn{3}{|c|}{ Gypsum- 0.50} & \multicolumn{3}{|c|}{ Gypsum-0.01 } & \multicolumn{3}{|c|}{ Gypsum-0.01 } \\
\hline & \multicolumn{3}{|c|}{ Sodic water x Gypsum- 0.91} & \multicolumn{3}{|c|}{ Sodic water x Gypsum- 0.02} & \multicolumn{3}{|c|}{ Sodic water x Gypsum- 0.02} \\
\hline
\end{tabular}

Table 5. Effect of sodic waters and gypsum on soil strength, EC and organic carbon content .

\begin{tabular}{|c|c|c|c|c|c|c|c|c|c|}
\hline \multirow{2}{*}{$\begin{array}{l}\text { Sodic } \\
\text { water } \\
\left(\text { me l}^{-1}\right)\end{array}$} & \multicolumn{3}{|c|}{ Soil pH } & \multicolumn{3}{|c|}{ ESP } & \multicolumn{3}{|c|}{ SAR } \\
\hline & $\mathbf{G}_{0}$ & $\mathbf{G}_{\mathbf{1 0 0}}$ & Mean & $\mathbf{G}_{0}$ & $\mathbf{G}_{100}$ & Mean & $\mathbf{G}_{\mathbf{0}}$ & $\mathbf{G}_{100}$ & Mean \\
\hline 2.8 & 9.18 & 9.18 & 9.18 & 32.00 & 32.00 & 32.00 & 31.55 & 31.55 & 31.55 \\
\hline 12.0 & 9.78 & 9.26 & 9.52 & 56.00 & 39.00 & 48.00 & 52.98 & 37.29 & 45.14 \\
\hline 16.0 & 9.89 & 9.43 & 9.66 & 63.00 & 45.00 & 55.00 & 66.23 & 41.96 & 54.10 \\
\hline Mean & 9.61 & 9.35 & & 50.00 & 39.00 & & 50.25 & 36.93 & \\
\hline $\mathrm{CD}(05)$ & $\begin{array}{l}\text { Sodic } \\
\text { Gypsu } \\
\text { Sodic }\end{array}$ & $\begin{array}{l}0.07 \\
7 \\
x \text { Gyps }\end{array}$ & 0.12 & $\begin{array}{l}\text { Sodic } \\
\text { Gypsu } \\
\text { Sodicu }\end{array}$ & $\begin{array}{l}1.51 \\
\text { Gypsur }\end{array}$ & & $\begin{array}{l}\text { Sodic } \\
\text { Gypsu } \\
\text { Sodic }\end{array}$ & $\begin{array}{l}-1.34 \\
34 \\
x \text { Gyps }\end{array}$ & 2.32 \\
\hline
\end{tabular}

mean of three replicates.

could be attributed to their ameliorative effects on soil infiltration rate which can be due to cementing/ bind- ing of separates by the $\mathrm{Ca} 2+$ ions, released during solubilisation of gypsum (Deshmukh, 2014). The interac- 
P.K.Yadav et al. / J. Appl. \& Nat. Sci. 8 (3): 1456 - 1461 (2016)

Table 6. Effect of sodic waters and gypsum on calcium carbon content (mean of three replicates).

\begin{tabular}{cccccc}
\hline Soil Depth & RSC 2.8 & \multicolumn{2}{c}{ RSC 12.0 } & \multicolumn{2}{c}{ RSC16.0 } \\
\cline { 2 - 6 }$(\mathbf{c m})$ & $\mathbf{G}_{\mathbf{0}}$ & $\mathbf{G}_{\mathbf{0}}$ & $\mathbf{G}_{\mathbf{1 0 0}}$ & $\mathbf{G}_{\mathbf{0}}$ & $\mathbf{G}_{\mathbf{1 0 0}}$ \\
\hline 0.15 & 0.56 & 0.67 & 0.94 & 0.84 & 1.21 \\
$15-30$ & 0.73 & 0.95 & 1.59 & 1.07 & 1.86 \\
$30-45$ & 0.88 & 1.39 & 1.71 & 1.60 & 2.64 \\
$45-60$ & 1.18 & 1.99 & 2.42 & 1.97 & 3.27 \\
$60-90$ & 1.68 & 2.19 & 2.74 & 2.41 & 3.86 \\
$90-12.00$ & 1.73 & 2.15 & 3.28 & 2.44 & 4.56 \\
CD $(05)$ & & RSC-0.07, Gypsum-0.07, RSCxGypsum-0.11 & \\
\hline
\end{tabular}

tion effects of RSC x gypsum was significant in affecting the infiltration rate of soil.

Soil porosity decreased with increasing RSC of irrigation water from 38.89 to 35.66 to 33.26 per cent with an increase in RSC level from 2.8 mel-1 to 12.0 to 16.0 me $1-1$, respectively (Table 3 ). The reduction in porosity of soils irrigated with high RSC waters (12.0 and 16.0 me1-1) could be attributed to higher degree of dispersion of soil particles with increasing level of RSC in irrigation water and subsequently resettling and reorganization of the dispersed soil particles according to their sizes and clogging the available pore space, resulting in high bulk density and hence lower soil porosity (Emdad et al., 2006 and Ezlit et al., 2010). Gypsum application improved soil porosity from 31.87 to 39.45 and from 28.70 to 37.81 per cent in 12.0 and 16.0 me1-1 RSC irrigation water irrigated soils, respectively. The increase in porosity by adding gypsum could be attributed to the reduction in dispersion of colloidal particles. The interaction effect of RSC x gypsum was found significant.

The dispersion ratio increased with increasing RSC levels and decreased with application of amendment. It was $0.17,0.20$ and 0.21 under $2.8,12.0$ and 16.0 RSC me1-1 levels in irrigation waters, respectively (Table 3). It is undoubtedly due to more dispersion of clay particles caused by higher amount of sodium content in irrigation waters having high level of RSC (Ezlit et al., 2010). It decreased from 0.20 to 0.19 with gypsum application. The interactive RSC x gypsum was found to be non-significant.

Soil strength, electrical conductivity and organic carbon : A significant increase in soil strength was observed up to RSC level of 12.0 me 1-1(Table 4). The soil strength was $15.53,17.49$ and $17.67 \mathrm{~kg} \mathrm{~cm}-2$ in the plots irrigated with 2.8, 12.0 and 16.0 me 1-1 RSC irrigation waters, respectively. Application of amendment gypsum significantly decreased soil strength and was 17.04 and $16.74 \mathrm{~kg} \mathrm{~cm}-2$ under $\mathrm{G}_{0}$ and $\mathrm{G}_{100}$ treatments, respectively. The interaction effect of RSC $\mathrm{x}$ gypsum was found significant. The EC of soil also significantly increased from 0.36 to $0.38 \mathrm{dSm}-1$ with increasing RSC from 2.8 to 12.0 and 16.0 me 1-1, respectively. Application of gypsum with sodic water of RSC 12.0 me 1-1 maintained the EC level statistically similar to that of good quality water (2.8 RSC) without gypsum application (Table 4). The interaction between RSC levels and amendments on soil EC was found to be significant. Decrease of EC in upper soil layer with gypsum application may be attributed to the leaching of soluble slats in gypsum treated plots due to increased permeability of the soil. These results are in agreement with those of Mishra et al. (2003) and Prapager et al. (2012). The mean organic carbon was $0.29,0.28$ and 0.23 per cent under 2.8, 12.0 and 16.0 RSC levels. (Table 4) and increased with gypsum application from 0.26 to $0.27 \%$ ). Singh et al. (2011) also observed that application of gypsum under sodic water irrigations enhanced the crop yield and improved soil properties like organic carbon content and EC. Deshmukh ( 2014) stated that the increase in yield due to the application of gypsum may be attributed due to less absorption of sodium by the plants in the presence of gypsum and increased solublization of gypsum with depth and thus better plant growth and higher organic carbon content.

Soil pH, exchangeable sodium percentage and sodium adsorption ratio: The mean soil $\mathrm{pH}$ was 9.18, 9.52 and 9.66 irrigated with $2.8,12.0$ and 16.0 me $1-1$ RSC water, respectively (Table 5). The soil pH with $12.0 \mathrm{mel}^{-1}$ (9.78) and $16.0 \mathrm{me} \mathrm{l}^{-1}$ (9.89) RSC waters without any amendment was significantly higher than the initial $\mathrm{pH}$ value of soil (9.25) when the experiment was started in 1983.The gypsum application decreased it to 9.26 and 9.43 indicating the significant effect of the gypsum in controlling sodicity hazard of high RSC waters. Neutralization of RSC of sodic water of 12.0 me 1-1 with gypsum maintained the $\mathrm{pH}$ values of the soil statistically at par to 2.8 me 1-1 RSC of water without gypsum after the harvest of crop. The interaction effect of RSC levels and amendment on soil pH was found to be significant. Significant effect of gypsum application (GR) in decreasing the soil $\mathrm{pH}$ may be attributed to the fact that $\mathrm{Ca} 2+$ ions from gypsum might have replaced exchangeable $\mathrm{Na}+$ from the exchange complex of soil resulting in decreased ESP and hence the pH of soil (Ezlit et al., 2010; Singh and Singh, 2014). Significant interaction between different RSC waters and amendments on soil $\mathrm{pH}$ could, therefore, be obvious as there had been varying proportions of sodium bicarbonate contents in different RSC waters used with different amendments and crop rotations.

The soil ESP was 32, 48 and 55 respectively, in 2.8, 12.0 and 16.0 RSC mel ${ }^{-1}$ water irrigated soils. The 
application of gypsum decreased the soil ESP to 39 and 45. The interaction between RSC levels and gypsum after harvest of crop was found to be significant. The build up of high ESP in soil under high RSC waters (12.0 and 16.0 me1-1) may be attributed to high sodium bicarbonate contents of these waters and proportionately greater amount of $\mathrm{Na}+$ ions from soil solution exchanged from exchangeable $\mathrm{Ca} 2+$ on the soil exchange complex. The highly significant effect of gypsum in controlling ESP of soil may be attributed to the fact that $\mathrm{Ca} 2+$ ions from gypsum exchanged for adsorbed $\mathrm{Na}+$, resulting in decrease in ESP. Ezlit et al. (2010) and Prapager et al. (2012) also observed that the application of gypsum significantly decreased the ESP values which can be ascribed to desalinization resulting from increased exchange-able efficiency of $\mathrm{Ca}^{2+}$ on the exchange complex. The reduced ESP could also imply greater effective solubility of gypsum since the cation exchange in the thoroughly mixed treatment acted as sink, thus, encouraging further dissolution to the satisfaction of their solubility product (Yudhuvanshi and Swarup, 2005).

The SAR of soil increased with increasing RSC of irrigation waters. The mean SAR was 31.55, 45.14 and 54.10 under 2.8, 12.0 and 16.0 RSC levels and application of gypsum decreased the SAR from 50.25 to 36.93 respectively, indicating a significant effect of amendment in controlling sodicity (Table 5). Significant interaction between RSC levels and amendments was observed. Significantly higher SAR under 12.0 and 16.0 RSC waters as compared to that under $2.8 \mathrm{RSC}$ water may be attributed to higher concentration of $\mathrm{Na}+$ ions in soil solution under the high RSC water treatments.

A close relationship between soil $\mathrm{pH}, \mathrm{SAR}$ and ESP with SAR of irrigation water exists. The sodium ions of sodic water significantly enhances sodium ions concentration on soil colloids which ultimately increase $\mathrm{pH}, \mathrm{SAR}$ and ESP of soil whereas, highly significant effect of gypsum in restricting $\mathrm{pH}$, SAR and ESP could be due to the reason that dissolution of gypsum released excess of $\mathrm{Ca} 2+$ ions in the soil solution which eventually exchanged for absorbed $\mathrm{Na}+$ ions (Makoi et al. 2010 and Prapager et al., 2012).

Calcium carbonate content : The calcium carbonate content of the soil was in traces at the start of the experiment in 1983. Increasing levels of RSC of the irrigation water increased the $\mathrm{CaCO} 3$ content of soil which was mainly due to continuous use of these RSC waters for last thirty years. Addition of gypsum also increased calcium carbonate content of soil with increasing depth of soil profile (Table 6). The calcium carbonate content increased from 0.94 and 1.21 per cent at $0-15$ $\mathrm{cm}$ depth to maximum of 3.15 and 3.31 per cent at 90 $120 \mathrm{~cm}$ soil profile depth in at $90-120 \mathrm{~cm}$ soil profile depth in RSC 12.0 and 16.0 mel-1. Thus keeping soil

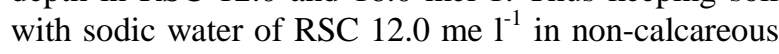
category $(<4 \% \mathrm{CaCO} 3)$ with addition of gypsum con- tinuously for thirty years. The effect of gypsum in increasing $\mathrm{CaCO} 3$ in soil profile was obvious because gypsum is a direct source of calcium and its addition in sodic water treated plots resulted in its precipitation as $\mathrm{CaCO} 3$ and increased its accumulation in different depths of a profile of loamy sand soil (Suarez, 2006).

\section{Conclusion}

Continuous use of sodic waters of 12.0 and 16.0 mel1 RSC for three decades without gypsum decreased infiltration rate and porosity of coarse textured soil whereas soil pH, ESP, SAR, $\mathrm{CaCO} 3$ content, dispersion ratio and soil strength showed an increasing trend with increasing RSC of irrigation waters. The adverse effect of sodic water of RSC 16.0 me 1-1 on soil properties was more pronounced compared to sodic water of RSC 12.0 me 1-1. Addition of gypsum significantly improved infiltration rate and porosity of soil irrigated with high RSC waters and decreased soil pH, ESP, SAR, dispersion ratio and soil strength. Gypsum application with sodic water of 16.0 mel-1 RSC was not much effective in offsetting the harmful effect of sodicity on soil properties as compared to 12.0 mel-1 RSC water. The calcium carbonate build up in soil was observed with gypsum application and its content further increased with soil depth and RSC of irrigation waters but the soil was still non-calcareous under sodic water irrigation with RSC 12.0 mel-1 and $16.0 \mathrm{mel}^{-1}$. Thus, it is concluded that in coarse textured soils of North west India, sodic waters up to RSC 12.0 me 1-1 could safely be used crop production in combination with gypsum in loamy sand soil without any adverse effect on the physico-chemical characteristics of soil

\section{ACKNOWLEDGEMENTS}

The authors are thankful to all soil scientists working in this long term experiment on safe use of sodic waters since 1983 at Regional Research Station, Bawal. The authors are also thankful to Regional Directors, RRS, Bawal and Professor and Head, Department of Soil Science, Chaudhary Charan Singh, Haryana Agricultural University,, Hisar for providing facilities, technical help and necessary guidance for this study.

\section{REFERENCES}

Deshmukh, K. 2014. Effect of gypsum on the chemistry of saline - sodic soils of Sangamner area,Ahmednagar District, Maharashtra, India. Athens: ATINER'S Conference Paper Series, No: ENV2014-1197.

Eaton, F.M. 1950. Significance of carbonates in irrigation waters. Soil Science 69, 127.

Emdad, M.R., Shahabifar, M. \& Fardad. 2006. Effect of different water qualities on

soil physical properties. Tenth International Water Technology Conference, IWTC10, Alexandria, Egypt.

Ezlit, Y.D., Smith R.J. \& Raine, S.R. 2010. A review of salinity and sodicity irrigation. Irrigation Mellers Series No.01/10.Cooperative Research Centre for Irrigation 
Futures.

Jackson, M. L. 1973. Soil Chemical Analysis. Prentice Hall of India Pvt. Ltd, New Delhi.

Makoi, J.H. J. R. \& Verplaneke, H. 2010. Effect of gypsum placement on the physico-chemical properties of a saline sandy loam soil. Australian Journal of Crop Science 4 (7), 556- 563.

Malik, R. S ., Sharma, S. K. \& Dhankhar, J . S . 1984 Design of a sensitive and practical closed- Top infiltrometer. Soil Science 139 (5), 452-457.

Mishra,A., Sharma S.D. \& Khan, G.H. 2003. Improvementin physical and chemical

properties of sodic soil by 3,6 , and 9 years old plantation of Eucalyptus tereticons in bio-rejuvenation of sodic soil. Forest Ecology Management 184,115-124

Panse, V.G. \& Sukhatme, P.V. 1978. Statistical Methods for Agriculture Workers.ICAR Publication, New Delhi.

Prapagar, K , Indraratne, S . P . \& Premanandharajah, P . 2012 . Effec $\mathrm{t}$ of Soil amend me $\mathrm{n}$ ts on reclamation of Saline-So d ic soil. T ropi cal Agri culture $R$ e search, 23 (2), 168 -176.

Puri, A. N. 1949 . Soils - Their Phys ics and Che mi st r y . Reinnolad Publ . Cor p n . Ne w York.

Ragab, R. 2005. Advances in integrated management of fresh water and saline water for sustainable crop production: Modeling and practical solutions. 78 (1-2): 1-164, Elsevier, Amaterdam.

Richards , L . A . ( e d s .), 1954. Diagnosis and improvement of saline and alkali soils. USDA Hand Book N o . 60 . Ox for d and IB H Pub. Co., New Delhi, India.

Sharma, D. R. \& Minhas, P.S. 2004. Soil properties and yields of upland crops as influenced by long-term use of water having variable residual alkalinity, salinity

and sodicity. Journal of the Indian Society of Soil Science 1, 100-104.

Singh, Y. P., Chauhan, S. V. S., Singh, H.C. \& Singh, S. 2011. Impact of Sodic Soil

Reclamation Technology: An assessment of On-Farm Trials. Journal of Indian Research.and Extension Education 11 (1), 70-73.

Singh, A., and Singh, J.K. 2014. Effect of Gypsum on the Reclamation and Soil Chemical Properties in Sodic Soils of Raebareli District, Uttar Pradesh. International Journal of Scientific Research in Environmental Sciences, 12, 429-434, 2014.

Suarez, D. L. 2006. Inorganic carbon: Land Use impacts Encyclopedia of Soil Science Second edition by R.Lal: 895-897.

Warrence, N. J., Pearson, Krista E. \& Bauder, J. W. 2003 Basics of salinity and sodicity effects on soil physical properties. Land Resources and Environmental Sciences

Department, Montana State University - Bozeman.

Yuduvanshi, N.P.S., Swarup, A., 2005. Effect of continuous use of sodic irrigation water with and without gypsum, farmyard manure, pressmud and fertilizer on soil properties and yields of rice and wheat in a long term experiment. Nutrient Cycling in Agro-ecosystems 73, 111-118.

Walkley, A. and Black, C.A. 1965. An examination of different methods for determining soil organic matter and a proposed modifications of the chromic acid titration method. Soil Science 37 : 29-38. 